\title{
IDENTIFIKASI MISKONSEPSI DAN PENYEBABNYA MENGGUNAKAN INSTRUMEN FIVE-TIER FLUID STATIC TEST (5TFST) PADA PESERTA DIDIK KELAS XI SEKOLAH MENENGAH ATAS
}

\section{SKRIPSI}

Diajukan untuk memenuhi salah satu syarat memperoleh gelar Sarjana Program Studi Pendidikan Fisika

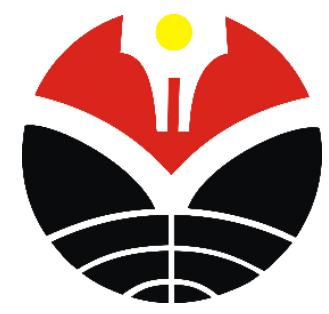

Oleh:

Sheila Mutiara Inggit 1606679

PROGRAM STUDI PENDIDIKAN FISIKA

FAKULTAS PENDIDIKAN MATEMATIKA DAN ILMU PENGETAHUAN

ALAM

UNIVERSITAS PENDIDIKAN INDONESIA

BANDUNG

2021 


\section{IDENTIFIKASI MISKONSEPSI DAN PENYEBABNYA MENGGUNAKAN \\ INSTRUMEN FIVE-TIER FLUID STATIC TEST (5TFST) PADA PESERTA DIDIK KELAS XI SEKOLAH MENENGAH ATAS}

SKRIPSI

Oleh:

Sheila Mutiara Inggit

1606679

Sebuah Skripsi yang diajukan untuk memenuhi sebagian syarat untuk memperoleh gelar sarjana pada Fakultas Pendidikan Matematika dan Ilmu Pengetahuan Alam

(C) Sheila Mutiara Inggit 2020

Universitas Pendidikan Indonesia

Januari 2021

Hak cipta dilindungi undang-undang.

Skripsi ini tidak boleh diperbanyak seluruhnya atau sebagian,

dengan dicetak ulang, di foto kopi, atau cara lainnya tanpa ijin dari penulis. 


\section{LEMBAR PENGESAHAN}

\section{IDENTIFIKASI MISKONSEPSI DAN PENYEBABNYA MENGGUNAKAN INSTRUMEN FIVE-TIER FLUID STATIC TEST (5TFST) PADA PESERTA DIDIK KELAS XI SEKOLAH MENENGAH ATAS}

Oleh:

\section{Sheila Mutiara Inggit}

1606679

disetujui dan disahkan oleh:

\section{Pembimbing I}

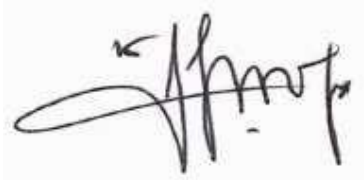

Dr. Winny Liliawati. S.Pd., M.Si.

NIP. 197812182001122001

\section{Pembimbing II}

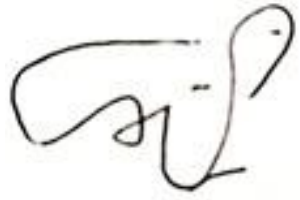

Drs. Iyon Suryana, M.Si.

NIP. 196208241991031001

Mengetahui,

\section{Ketua Prodi Pendidikan Fisika}

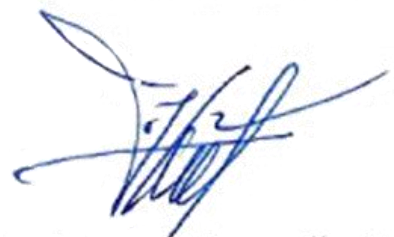

Dr. Achmad Samsudin, M.Pd.

NIP. 198310072008121004 


\section{SURAT PERNYATAAN}

Dengan ini saya menyatakan bahwa skripsi dengan judul "Identifikasi Miskonsepsi dan Penyebabnya Menggunakan Instrumen Five-Tier Fluid Static Test (5TFST) Pada Peserta Didik Kelas XI Sekolah Menengah Atas" ini beserta seluruh isinya merupakan benar-benar hasil karya sendiri. Saya tidak melakukan penjiplakan atau pengutipan dengan cara-cara yang tidak sesuai etika ilmu yang berlaku dalam masyarakat keilmuan. Atas pernyataan ini, saya siap menanggung risiko/sanksi apabila di kemudian hari ditemukan adanya pelanggaran etika keilmuan atau ada klaim dari pihak lain terhadap keaslian karya saya ini.

Bandung, Yang membuat pernyataan, 


\section{KATA PENGANTAR}

Puji dan syukur kita panjatkan kehadirat Allah SWT yang telah melimpahkan rahmat serta hidayah-Nya sehingga penulis bisa menyelesaikan skripsi yang berjudul "Identifikasi Miskonsepsi dan Penyebabnya Menggunakan Instrumen Five-Tier Fluid Static Test (5TFST) Pada Peserta Didik Kelas XI Sekolah Menengah Atas" yang merupakan bagian dari payung penelitian Dr. Winny Liliawati, M.Si. Skripsi ini disusun untuk memenuhi salah satu syarat mendapatkan gelar Sarjana Pendidikan Fisika. Semoga skripsi ini dapat membantu para rekan yang akan melakukan penelitian seperti ini ataupun yang membutuhkan rujukan penelitian miskonsepsi dan penyebab miskonsepsi. Penelitian ini juga dapat menjadi gambaran miskonsepsi materi fluida statis yang terjadi pada peserta didik SMA.

Dalam penulisan skripsi ini penulis menyadari bahwa skripsi ini terdapat banyak kekurangan dan keterbatasan. Oleh karena itu penulis memohon maaf atas kekurangan dan keterbatasan tersebut karena penulis pun masih dalam proses belajar.

Bandung, Januari 2021

Penulis,

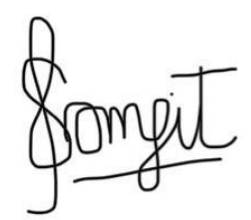

Sheila Mutiara Inggit

Sheila Mutiara Inggit, 2021

IDENTIFIKASI MISKONSEPSI DAN PENYEBABNYA MENGGUNAKAN INSTRUMEN FIVE-TIER FLUID

STATIC TEST (5TFST) PADA PESERTA DIDIK KELAS XI SEKOLAH MENENGAH ATAS

Universitas Pendidikan Indonesia | repository.upi.edu | perpustakaan.upi.edu 


\section{UCAPAN TERIMA KASIH}

Bismillahirrahmanirrahim.

Puji syukur kehadirat Allah SWT atas rahmat dan karunia-Nya sehingga penulis dapat menyelesaikan skripsi ini. Selain itu, penulis juga ingin mengucapkan terimakasih kepada pihak-pihak yang membantu dalam penyelesaian skripsi ini dalam bentuk semangat, motivasi, dukungan, dan pastinya doa yang diberikan. Ucapan terimakasih tersebut penulis sampaikan kepada:

1. Kedua orang tua dan saudara penulis yang senantiasa memberikan doa dan dukungan yang tak henti-hentinya untuk penulis.

2. Ibu Dr. Winny Liliawati, M.Si. selaku Dosen Pembimbing I sekaligus Dosen Payung Penelitian yang telah banyak memberikan bimbingan, saran, motivasi, nasehat, kritik dengan sabar sehingga penulis dapat menyelesaikan skripsi ini.

3. Bapak Drs. Iyon Suryana, M.Si. selaku Dosen Pembimbing II yang telah banyak memberikan bimbingan, saran, motivasi, nasehat, kritik dengan sabar sehingga penulis dapat menyelesaikan skripsi ini.

4. Ibu Dra. Heni Rusnayati, M.Si. selaku Dosen Pembimbing Akademik yang telah memberikan doa, semangat, motivasi, serta bimbingannya selama penulis berkuliah di Pendidikan Fisika FPMIPA UPI.

5. Para dosen dan guru fisika yang telah berkenan dan meluangkan waktunya untuk menjadi validator dan memberikan masukan pada instrumen skripsi sehingga instrument layak untuk digunakan.

6. Eca Nurjanah, Hidiyah Marthia dan Mawar Fatia yang telah menjadi tempat penulis mencurahkan keluh kesah selama ini.

7. Nurul Nasyithotul Jannah yang telah menjadi teman seperjuangan selama perkuliahan dan menjadi partner kamar yang selalu memberi dukungan kepada penulis. 
8. Imas Rosita, Farah Salmadhia, Sofie Nurfadila, Sylvi Aidia, Nurul NJ dan Hijrotun Darojat Utami sebagai teman-teman seperjuangan payung penelitian yang telah memberikan semangat satu sama lain.

9. Teman-teman seangkatan Departemen Pendidikan Fisika sebagai teman seperjuangan selama berkuliah.

10. Serta semua pihak yang tidak bisa penulis sebutkan satu satu. Terimakasih atas segala dukungan, kritik, saran, serta kebaikan yang telah diberikan kepada penulis.

Sekali lagi, penulis mengucapkan banyak terima kasih kepada seluruh pihak yang terlibat, semoga selalu dilindungi oleh Allah SWT dan selalu diberikan kesehatan serta kebahagiaan yang berlimpah. 


\title{
Identifikasi Miskonsepsi dan Penyebabnya Menggunakan Instrumen Five- Tier Fluid Static Test (5TFST) pada Peserta Didik Kelas XI Sekolah
}

\author{
Menengah Atas
}

\author{
Sheila Mutiara Inggit*, Winny Liliawati, Iyon Suryana
}

Departemen Pendidikan Fisika. FPMIPA, Universitas Pendidika Indonesia, Jalan Dr. Setiabudi 229 Bandung 40154, Indonesia

*Email: sheilainggit@student.upi.edu

HP: 087811858373

\begin{abstract}
ABSTRAK
Miskonsepsi merupakan masalah yang akan menghambat proses pembelajaran. Untuk mengatasi masalah itu harus mengidentifikasi ada tidaknya miskonsepsi. Penelitian ini bertujuan untuk mengidentifikasi miskonsepsi dan penyebabnya pada materi fluida statis. Metode yang digunakan dalam penelitian ini adalah metode deskriptif kuantitatif eksploratif. Penelitian ini dilaksanakan di salah satu SMA Negeri di Kota Bandung dan dua SMA Negeri di Kab. Kuningan dengan jumlah partisipan 217 peserta didik (72 laki-laki dan 145 perempuan). Instrumen yang digunakan dalam mengidentifikasi miskonsepsi ini adalah Five-Tier Fluid Static Test (5TFST) yang terdiri dari 11 butir soal pilihan ganda lima tingkat. Penelitian ini menggunakan analisis $C D Q$ (Confidence Discrimination Quotient). Berdasarkan hasil analisis $C D Q$ menunjukkan bahwa terdapat 17 miskonsepsi yang teridentifikasi. Persentase miskonsepsi tertinggi yaitu $81 \%$ pada konsep tekanan hidrostatis. Penyebab miskonsepsi yang terdeteksi dalam penelitian ini adalah pemikiran peserta didik dan penjelasan guru. Berdasarkan hasil pengolahan data, diketahui bahwa instrumen Five-Tier Fluid Static Test (5TFST) menggunakan teknik analisis $C D Q$ dapat mengidentifikasi miskonsepsi apa saja yang dialami oleh peserta didik dan penyebab miskonsepsi yang terjadi pada peserta didik pada materi fluida statis.
\end{abstract}

Kata Kunci: five-tier diagnostic test, miskonsepsi, penyebab miskonsepsi

Sheila Mutiara Inggit, 2021

iv

IDENTIFIKASI MISKONSEPSI DAN PENYEBABNYA MENGGUNAKAN INSTRUMEN FIVE-TIER FLUID

STATIC TEST (5TFST) PADA PESERTA DIDIK KELAS XI SEKOLAH MENENGAH ATAS

Universitas Pendidikan Indonesia | repository.upi.edu | perpustakaan.upi.edu 


\title{
Identify Misconception and Causes of Misconception using Five-Tier Fluid Static Test (5TFST) Instrument in Grade XI High School Students Sheila Mutiara Inggit*, Winny Liliawati, Iyon Suryana Department of Physics Education. FPMIPA, Indonesia University of Education, Jalan Dr. Setiabudi 229 Bandung 40154, Indonesia \\ *Email: sheilainggit@student.upi.edu \\ HP: 087811858373
}

\begin{abstract}
Misconceptions are problem that will hinder the learning process if ignored continuously. To solve the problem, must identify the existence of misconception. This study aims to identify misconceptions and their causes about static fluid. The research method used is a descriptive-explorative method. This research was conducted in one of public high schools in Bandung and two public high schools in Kuningan District with a total of 217 students (72 male students and 145 female students). The instrument used to identify this misconception is the Five-Tier Fluid Static Test (5TFST) which consists of 11 items of fivetier multiple selection. This study used $C D Q$ (Confidence Discrimination Quotient) analysis. Based on $C D Q$ analysis results showed that there were 17 misconceptions identified. The highest percentage of misconceptions is $81 \%$ in hydrostatic pressure concepts. The source of the misconceptions identified in this study were the students' thinking and the teacher's explanation. Based on the data processing results, it is known that the Five-Tier Fluid Static Test (5TFST) instrument using CDQ analysis techniques can identify what misconceptions are experienced by students and the causes of misconceptions that occur in students in static fluid material.
\end{abstract}

Keywords: five-tier diagnostic test, misconception, causes of misconception

Sheila Mutiara Inggit, 2021

V

IDENTIFIKASI MISKONSEPSI DAN PENYEBABNYA MENGGUNAKAN INSTRUMEN FIVE-TIER FLUID

STATIC TEST (5TFST) PADA PESERTA DIDIK KELAS XI SEKOLAH MENENGAH ATAS

Universitas Pendidikan Indonesia | repository.upi.edu | perpustakaan.upi.edu 


\section{DAFTAR ISI}

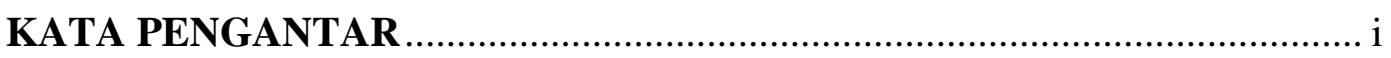

UCAPAN TERIMA KASIH ..................................................................... ii

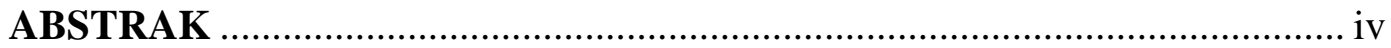

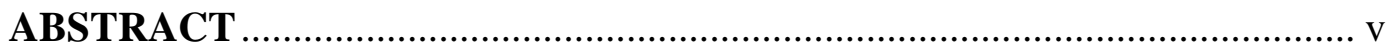

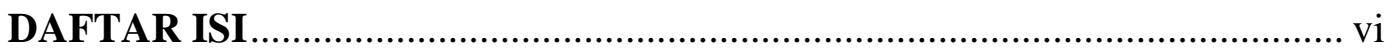

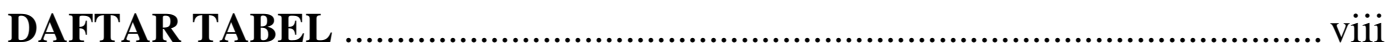

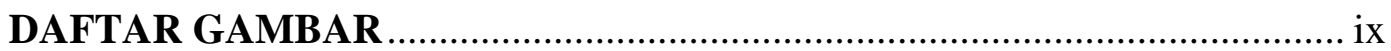

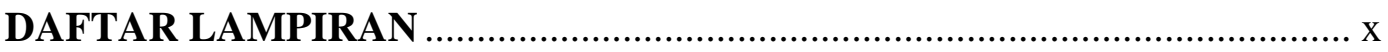

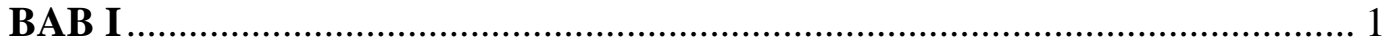

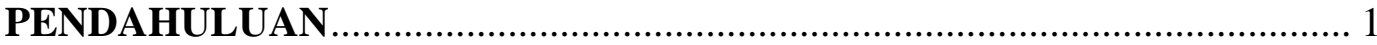

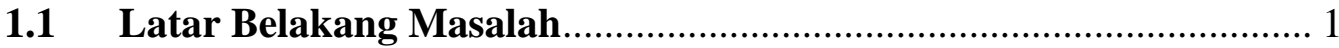

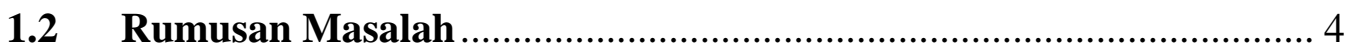

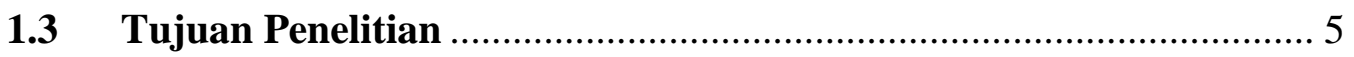

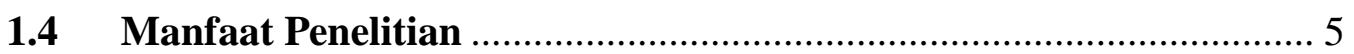

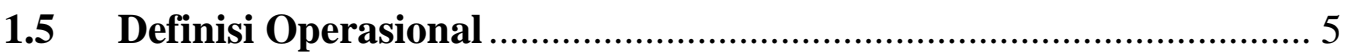

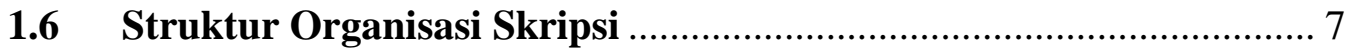

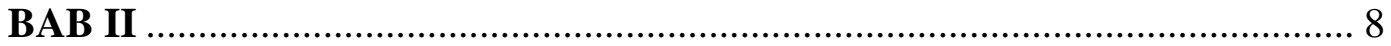

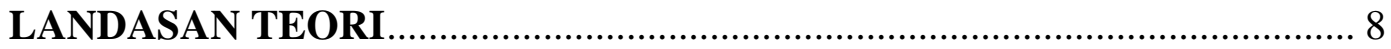

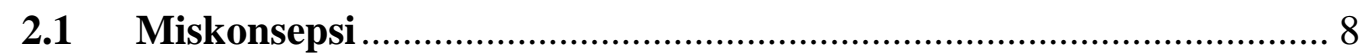

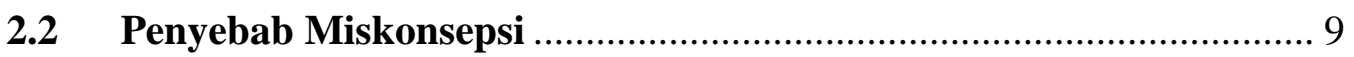

2.3 Instrumen Tes Diagnostik ....................................................... 10

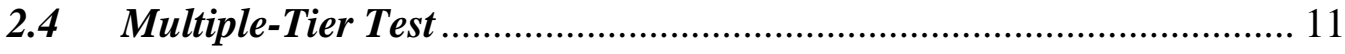

2.5 Miskonsepsi dalam Fluida Statis............................................... 13

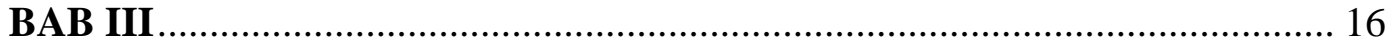

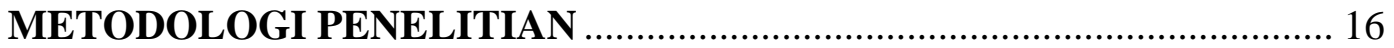

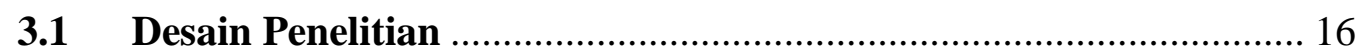

3.2 Partisipan Penelitian .................................................................... 16

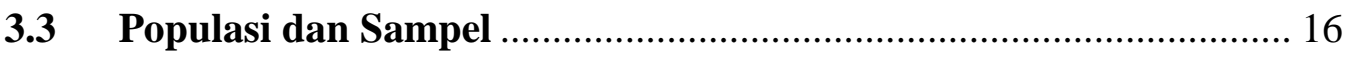

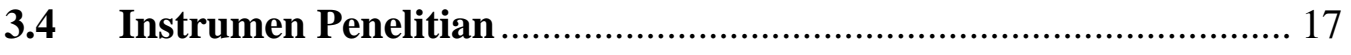

Sheila Mutiara Inggit, 2021

IDENTIFIKASI MISKONSEPSI DAN PENYEBABNYA MENGGUNAKAN INSTRUMEN FIVE-TIER FLUID STATIC TEST (5TFST) PADA PESERTA DIDIK KELAS XI SEKOLAH MENENGAH ATAS

Universitas Pendidikan Indonesia | repository.upi.edu | perpustakaan.upi.edu 
3.4.1 Five-Tier Fluid Static Test (5TFST) .......................................... 17

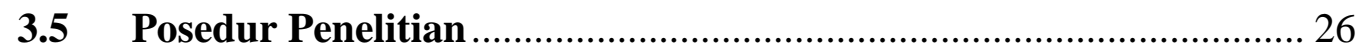

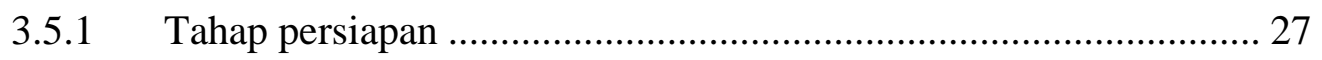

3.5.2 Tahap pelaksanaan ................................................................ 27

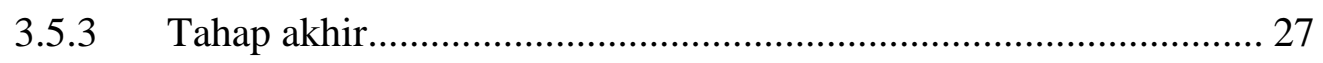

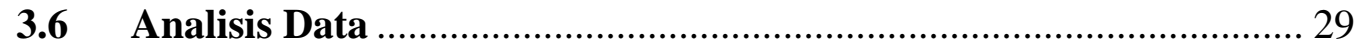

3.6.1 Miskonsepsi Peserta didik............................................................. 29

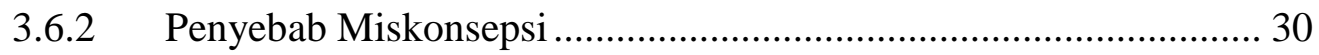

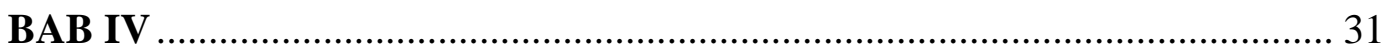

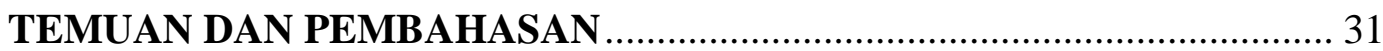

4.1 Profil Miskonsepsi Peserta Didik pada Materi Fluida Statis .......... 31

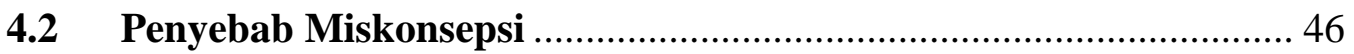

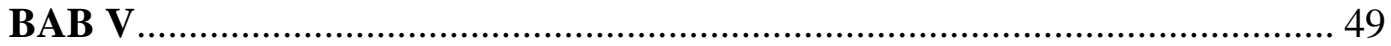

SIMPULAN, IMPLIKASI DAN REKOMENDASI .................................... 49

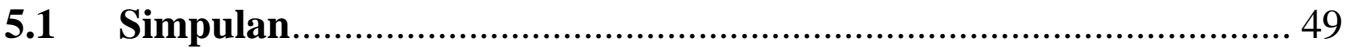

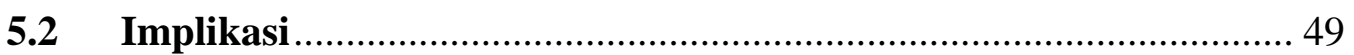

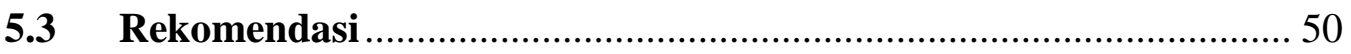

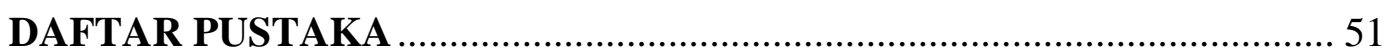

Sheila Mutiara Inggit, 2021

vii

IDENTIFIKASI MISKONSEPSI DAN PENYEBABNYA MENGGUNAKAN INSTRUMEN FIVE-TIER FLUID STATIC TEST (5TFST) PADA PESERTA DIDIK KELAS XI SEKOLAH MENENGAH ATAS

Universitas Pendidikan Indonesia | repository.upi.edu | perpustakaan.upi.edu 


\section{DAFTAR TABEL}

Tabel 2.1 Penyebab miskonsepsi pada peserta didik ........................................ 9

Tabel 2.2 Miskonsepsi materi fluida statis ..................................................... 13

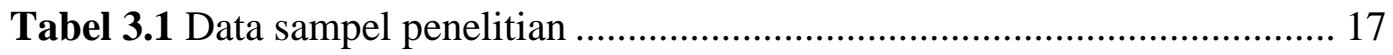

Tabel 3.2 Desain Five-Tier Fluid Static Test (5TFST) .................................... 17

Tabel 3. 3 Klasifikasi Validasi Isi Instrumen ................................................... 20

Tabel 3.4 Hasil Validasi Ahli pada Instrumen Five-Tier Fluid Static Test......... 20

Tabel 3.5 Kriteria validitas butir soal berdasarkan analisis Rasch model ........... 21

Tabel 3.6 Hasil uji validitas butir soal pada tingkat-1 menggunakan analisis Rasch

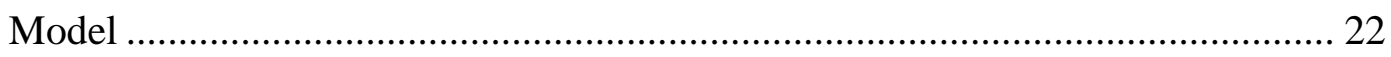

Tabel 3.7 Hasil uji validitas butir soal pada tingkat-3 menggunakan analisis Rasch Model 22

Tabel 3.8 Hasil uji validitas butir soal pada tingkat-1 dan tingkat-3 menggunakan analisis Rasch Model. 23

Tabel 3.9 Kriteria reliabilitas untuk nilai Cronbach Alpha ................................ 23

Tabel 3.10 Kriteria reliabilitas person dan reliabilitas item .............................. 24

Tabel 3.11 Hasil uji reliabilitas butir soal pada tingkat-1 .................................. 24

Tabel 3.12 Hasil uji reliabilitas butir soal pada tingkat-3 ................................. 25

Tabel 3.13 Hasil uji reliabilitas butir soal pada tingkat-1 dan tingkat-3 ............. 25

Tabel 3.14 Hasil Reliabilitas ................................................................................ 26

Tabel 4.1 Hasil pengolahan nilai CDQ per tingkat dan butir soal...................... 32

Tabel 4.2 Miskonsepsi apa saja yang teridentifikasi pada butir soal .................. 33

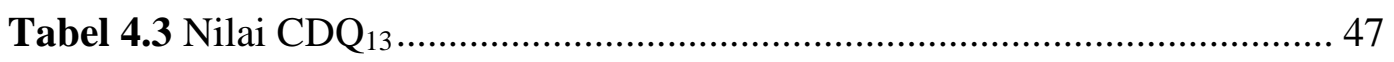

Tabel 4.4 Hasil pengolahan nilai CDQp sumber penyebab ................................ 47

Sheila Mutiara Inggit, 2021

viii

IDENTIFIKASI MISKONSEPSI DAN PENYEBABNYA MENGGUNAKAN INSTRUMEN FIVE-TIER FLUID STATIC TEST (5TFST) PADA PESERTA DIDIK KELAS XI SEKOLAH MENENGAH ATAS

Universitas Pendidikan Indonesia | repository.upi.edu | perpustakaan.upi.edu 


\section{DAFTAR GAMBAR}

Gambar 3.1 Contoh format data diri pada google formulir ............................. 18

Gambar 3.2 Contoh butir soal 5TFST pada google-formulir ........................... 19

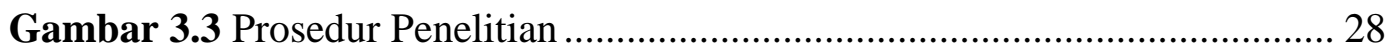

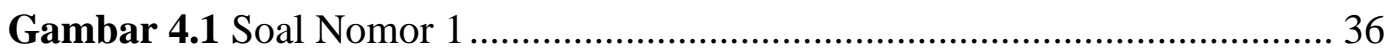

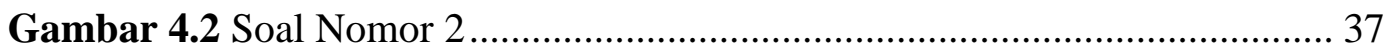

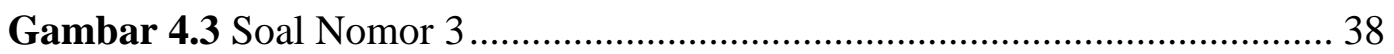

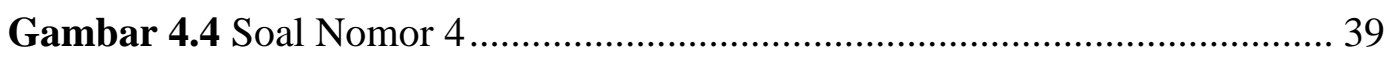

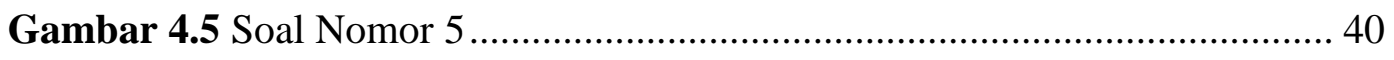

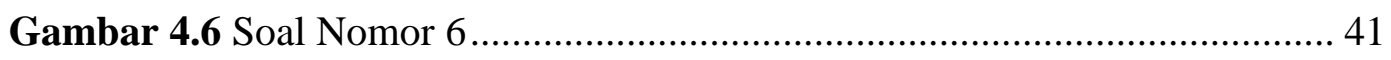

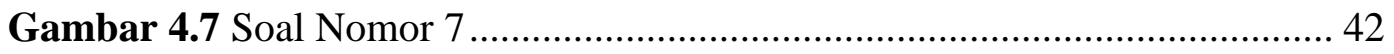

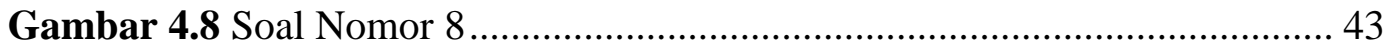

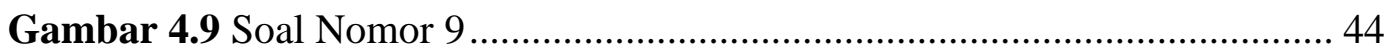

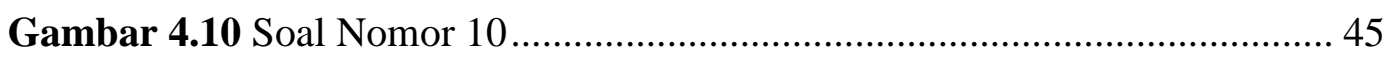

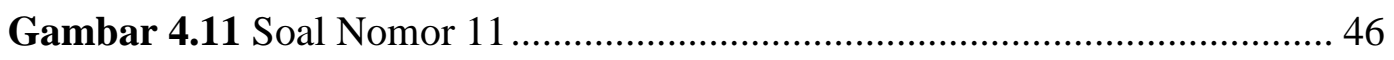

Sheila Mutiara Inggit, 2021 


\section{DAFTAR LAMPIRAN}

\section{LAMPIRAN A: INSTRUMEN PENELITIAN}

Lampiran A.1: Kisi-kisi Instrumen Penelitian Five-Tier Fluid Static Test (5TFST)

Lampiran A.2: Naskah Instrumen Five-Tier Fluid Static Test (5TFST) 75

Lampiran A.3: Lembar Judgement Validasi Ahli 91

Lampiran A.4: Hasil Validasi Ahli 94

\section{LAMPIRAN B: PENGOLAHAN DATA}

Lampiran B. 1: Pengolahan Validasi Soal 104

Lampiran B.2: Pengolahan Reliabilitas Soal 107

Lampiran B.3: Distribusi Jawaban Peserta Didik 109

\section{LAMPIRAN C: BERKAS-BERKAS}

Lampiran C.1: SK Pembimbing Skripsi .................................................... 145

Lampiran C. 2: Agenda Bimbingan Skripsi................................................ 147

Lampiran C. 3: Dokumentasi Penelitian...................................................... 152 


\section{DAFTAR PUSTAKA}

Ahsin, A. (2017). Konstruksi Four-Tier Test dengan Integrasi Angket yang Difokuskan Untuk Mengidentifikasi Level dan Penyebab Miskonsepsi pada Materi Kalor Tingkat SMA. Universitas Pendidikan Indonesia.

Alwan, A. A. (2011). Misconception of heat and temperature among physics students. Procedia - Social and Behavioral Sciences, 12, 600-614. https://doi.org/10.1016/j.sbspro.2011.02.074

Amin, N., Wiendartun, \& Samsudin, A. (2016). Analisis Intrumen Tes Diagnostik Dynamic-Fluid Conceptual Change Inventory ( DFCCI ) Bentuk Four-Tier Test pada Beberapa SMA di Bandung Raya. Prosiding SNIPS, 570-574.

Anam, R. S., Widodo, A., Sopandi, W., \& Wu, H. K. (2019). Developing a five-tier diagnostic test to identify students' misconceptions in science: an example of the heat transfer concepts. Elementary Education Online, 18(3), 1014-1029. https://doi.org/10.17051/ilkonline.2019.609690

Arikunto, S. (2002). Prosedur Penelitian: Suatu Pendekatan Praktek. Jakarta: PT Rineka Cipta.

Arikunto, S. (2010). Manajemen Penelitian. Jakarta: Rineka Cipta.

Artiawati, P. R., Muliyani, R., \& Kurniawan, Y. (2018). Identifikasi Kuantitas Siswa yang Miskonsepsi Menggunakan Three Tier-Test Pada Materi Gerak Lurus Berubah Beraturan (GLBB). JIPF (Jurnal Ilmu Pendidikan Fisika), 3(1), 5. https://doi.org/10.26737/jipf.v3i1.331

Azwar, S. (2012). Reliabilitas dan Validitas (Edisi 4). Yogyakarta: Pustaka Pelajar.

Cahyani, H., Samsudin, A., Tarigan, D. E., Kaniawati, I., Suhendi, E., Suyana, I., \& Danawan, A. (2019). Identifikasi miskonsepsi fluida statis pada siswa SMA menggunakan four-tier diagnostic test. Prosiding Seminar Nasional Fisika

51

Sheila Mutiara Inggit, 2021

IDENTIFIKASI MISKONSEPSI DAN PENYEBABNYA MENGGUNAKAN INSTRUMEN FIVE-TIER FLUID

STATIC TEST (5TFST) PADA PESERTA DIDIK KELAS XI SEKOLAH MENENGAH ATAS

Universitas Pendidikan Indonesia | repository.upi.edu | perpustakaan.upi.edu 
$5.0,0$

Caleon, I. S., \& Subramaniam, R. (2010). Do students know What they know and what they don't know? Using a four-tier diagnostic test to assess the nature of students' alternative conceptions. Research in Science Education, 40(3), 313337. https://doi.org/10.1007/s11165-009-9122-4

Caleon, I., \& Subramaniam, R. (2010). Development and application of a three-tier diagnostic test to assess secondary students' understanding of waves. International Journal of Science Education, 32(7), 939-961. https://doi.org/10.1080/09500690902890130

Dirjen Manajemen Pendidikan Dasar dan Menengah. (2007). Tes Diagnostik. Jakarta: Depdiknas.

Fariyani, Q., Rusilowati, A., \& Sugianto. (2015). Pengembangan Four-Tier Diagnostic Test Untuk Mengungkap Miskonsepsi Fisika Siswa Sma Kelas X. Journal of Innovative Science Education, 4(2), 41-49.

Hermita, N., Suhandi, A., Syaodih, E., Samsudin, A., Isjoni, Johan, H., ... Safitri, D. (2017). Constructing and Implementing a Four Tier Test about Static Electricity to Diagnose Pre-service Elementary School Teacher' Misconceptions. Journal of Physics: Conference Series, 895(1). https://doi.org/10.1088/1742-6596/895/1/012167

Kabapinar, F. F. M. E. T. (2005). Effectiveness of Teaching via Concept Cartoons from the Point of View of Constructivist Approach. Educational Sciences: Theory \& Practice, 5(1), 135-146. Diambil dari http://search.ebscohost.com/login.aspx?direct=true \&db=eue \&AN=17364596 \&site=ehost-live

Kaltakçi, D., \& Didiç, N. (2007). Identification of pre-service physics teachers' misconceptions on gravity concept: A study with a 3-tier misconception test. AIP Conference Proceedings, Vol. 899, hal. 499-500. 
https://doi.org/10.1063/1.2733255

Kaltakci, D., Eryilmaz, A., \& McDermott, L. C. (2015). A Review and Comparison of Diagnostic Instruments to Identify Students' Misconceptions in Science. Eurasia Journal of Mathematics, Science and Technology Education, 11(5), 989-1008. https://doi.org/10.12973/eurasia.2015.1369a

Nurulwati., Veloo, A., Ali, R. (2014). Suatu Tinjauan Tentang Jenis-Jenis dan Penyebab Miskonsepsi Fisika. Jurnal Pendidikan Sains Indonesia. 02(01), 8795.

Prastiwi, V. D., \& Wisodo, H. (2017). Profil Pemahaman Konsep Siswa SMA pada Materi Fluida Statis. Prosidinh Seminar Pendidikan IPA Pascasarjana UM, 2(2013), 325-332.

Retnawati, H. (2016). Analisis Kuantitatif Instrumen Penelitian. Parama Publishing.

Saputra, O., Setiawan, A., \& Rusdiana, D. (2019). Identification of Student Misconception About Static Fluid. Journal of Physics: Conference Series, 1157(3). https://doi.org/10.1088/1742-6596/1157/3/032069

Setiawati, W. E., \& Jatmiko, B. (2018). Penerapan Model Pembelajaran Inkuiri Terbimbing Untuk Meningkatkan Pemahaman Konsep Fisika Siswa SMA. Issn, 07(02), 287-291.

Sholihat, F. N., Samsudin, A., \& Nugraha, M. G. (2017). Identifikasi Miskonsepsi dan Penyebab Miskonsepsi Siswa Menggunakan Four-Tier Diagnostic Test Pada Sub-Materi Fluida Dinamik: Azas Kontinuitas. Jurnal Penelitian \& Pengembangan Pendidikan Fisika, 3(2), 175-180. https://doi.org/10.21009/1.03208

Sugiyono. (2015). Metode Penelitian Pendidikan. Bandung: Alfabeta.

Sukardi. (2013). Metodologi Penelitian Pendidikan Kompetensi dan Praktiknya.

Sheila Mutiara Inggit, 2021

53

IDENTIFIKASI MISKONSEPSI DAN PENYEBABNYA MENGGUNAKAN INSTRUMEN FIVE-TIER FLUID

STATIC TEST (5TFST) PADA PESERTA DIDIK KELAS XI SEKOLAH MENENGAH ATAS

Universitas Pendidikan Indonesia | repository.upi.edu | perpustakaan.upi.edu 
Jakarta: Bumi Aksara.

Sumaji, Drost, Josephus, Ignatius, Gerardus, \& Maria. (1998). Pendidikan Sains yang Humanistis. Yogyakarta: Kanisius.

Sumintono, B., \& Widhiarso, W. (2015). Aplikasi Pemodelan Rasch pada Assessment Pendidikan. Trim Komunikasi.

Suparno, P. (2013). Miskonsepsi dan Perubahan Konsep dalam Pendidikan Fisika. Jakarta: PT. Grasindo.

Susanti, D., Waskito, S., \& Surantoro, S. (2014). Penyusunan Instrumen Tes Diagnostik Miskonsepsi Fisika Sma Kelas Xi Pada Materi Usaha Dan Energi. Jurnal Pendidikan Fisika Universitas Sebelas Maret, 2(2), 16-19.

Sutopo. (2016). Students' Understanding of Fundamental Concepts of Mechanical Wave. Jurnal Pendidikan Fisika Indonesia, 12(1), 41-53. https://doi.org/10.15294/jpfi.v12i1.3804

Suwarto. (2013). Pengembangan Tes Diagnostik dalam Pembelajaran. Yogyakarta: Pustaka Pelajar.

Syahrul, D., \& Setyarsih, W. (2015) Identifikasi Miskonsepsi dan Penyebab Miskonsepsi dengan Three-tier Diagnostic Test Pada Materi Dinamika Rotasi. Jurnal Inovasi Pendidikan Fisika (JIPF).04(03), 67-70.

Taslidere, E. (2016). Development and use of a three-tier diagnostic test to assess high school students' misconceptions about the photoelectric effect. Research in Science and Technological Education, 34(2), 164-186. https://doi.org/10.1080/02635143.2015.1124409

Treagust, D. (1986). Evaluating Students Misconceptions by Means of Diagnostic Multiple Choise Items. Research in Science Education, 9(1978), 123-128.

Utami, R., Djudin, T., \& Arsyid, S. B. (2014). Remediasi Miskonsepsi Pada Fluida 
Statis Melalui Model Pembelajaran TGT Berbantuan Mind Mapping Di Sma. Jurnal Pendidikan dan Pembelajaran, 1-12.

Wahyuningsih, T., Raharjo, T., \& Fitriana Masithoh, D. (2013). Pembuatan Instrumen Tes Diagnostik Fisikasma Kelas XI. Jurnal Pendidikan Fisika, 1(1), 111-117.

Wang, J. R. (2004). Development and validation of a two-tier instrument to examine understanding of internal transport in plants and the human circulatory system. International Journal of Science and Mathematics Education, 2(2), 131-157. https://doi.org/10.1007/s10763-004-9323-2

Wartono, Saifullah, A. M., \& Sugiyanto. (2016). Identifikasi Miskonsepsi Siswa Kelas X pada Materi Fluida Statis dengan Instrumen Diagnostik Three-Tier. Jurnal Pendidikan dan Pembelajaran, 23(April), 20-26.

Yudhitiara, R. F., Hindarto, N., \& Mosik. (2017). Identifikasi Miskonsepsi Menggunakan CRI dan Penyebabnya Pada Materi Mekanika Fluida Kelas XI Sma. Unnes Physics Education Journal, 6(2), 81-89. https://doi.org/10.15294/upej.v6i2.16076 